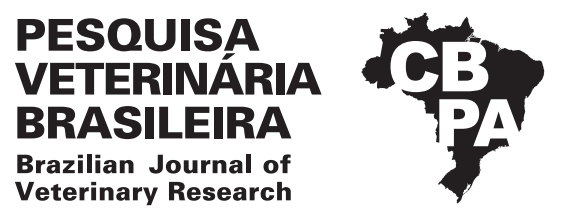

Pesq. Vet. Bras. 39(4):238-243, April 2019 DOI: 10.1590/1678-5150-PVB-6118

Original Article

ISSN 0100-736X (Print) Livestock Diseases

ISSN 1678-5150 (Online)

\title{
Experimental reproduction of cyanogenic poisoning by star grass (Cynodon nlemfuensis Vanderyst var. nlemfuensis cv. "Florico") in cattle ${ }^{1}$
}

\author{
Franciéli Adriane Molossi² (D), Daiane Ogliari², Elaine Melchioretto², \\ Gustavo Felipe G.P. Hugen ${ }^{2}$, Lucas S. Quevedo ${ }^{2}$, Julio M. Vettori ${ }^{2}$ and Aldo Gava ${ }^{2 *}$ (IC)
}

\begin{abstract}
Molossi F.A., Ogliari D., Melchioretto E., Hugen G.F.G.P., Quevedo L.S., Vettori J.M. \& Gava A. 2019. Experimental reproduction of cyanogenic poisoning by star grass (Cynodon nlemfuensis Vanderyst var. nlemfuensis cv. "Florico") in cattle. Pesquisa Veterinária Brasileira 39(4):238-243. Laboratório de Patologia Animal, Departamento de Medicina Veterinária, Centro de Ciências Agroveterinárias, Universidade do Estado de Santa Catarina, Av. Luiz de Camões 2090, Lages, SC 88520-000, Brazil. E-mail: aldo.gava@udesc.br

We experimentally reproduced star grass (Cynodon nlemfuensis Vanderyst var. nlemfuensis cv. "Florico") poisoning in cattle. Star grass was planted in four shaded $(1,2,3$, and 4$)$ and three sunny paddocks (5, 6, and 7) and were fertilized with the equivalent of $0,750,200$, or $100 \mathrm{~kg} / \mathrm{ha}$ urea. Fresh plant leaves were collected from each paddock and fed to 8 calves aged 5 months to 1 year at $10 \mathrm{~g} / \mathrm{kg}$ live weight. Clinical examinations were performed pre- and post-feeding. Fresh leaves were also subjected to sodium picrate paper and diphenylamine tests to evaluate hydrocyanic acid and nitrate concentration, respectively. Clinical signs of poisoning by the star grass cv. "Florico" in cattle were observed 5-15 minutes after ingestion; these included wobbling, muscle tremors, frequent and/or dripping urination, tachycardia, ruminal atony, depression, red ocular mucous membranes, and bright red venous blood. Three animals became severely ill, 4 manifested mild to moderate clinical signs, and 1 did not become ill. The 3 severely ill bovines received a thiosulfate and sodium nitrite solution at a dose of $40 \mathrm{ml} / 100 \mathrm{~kg}$ live weight, intravenously (IV). Florico star grass poisoned bovines and the reaction to the sodium picrate paper and diphenylamine tests was more significant for samples cultivated in the shade and with high nitrogen fertilization. Florico grass utilization should be avoided in a silvopastoral system.
\end{abstract}

INDEX TERMS: Experimental reproduction, cyanogenic poisoning, star grass, Cynodon nlemfuensis, Florico cultivar, cattle, hydrocyanic acid, shadow, bovine.

\begin{abstract}
RESUMO.- [Reprodução experimental de intoxicação cianogênica por grama estrela (Cynodon nlemfuensis Vanderyst var. nlemfuensis cv. "Florico") em bovinos.] Descreve-se a reprodução experimental da intoxicação cianogênica por grama estrela (Cynodon nlemfuensis vanderyst var. nlemfuensis cv. 'Florico') em bovinos. A grama estrela foi plantada em quatro piquetes em área sombreada $(1,2,3$ e 4) e em três piquetes em área ensolarada $(5,6$ e 7$)$ e foram adubados com o equivalente a $0,750,200$ ou $100 \mathrm{~kg} /$ ha de ureia. Folhas
\end{abstract}

\footnotetext{
${ }^{1}$ Received on October 25, 2018.

Accepted for publication on December 12, 2018.

Part of the Master's Thesis of the first author.

${ }^{2}$ Laboratório de Patologia Animal, Departamento de Medicina Veterinária, Centro de Ciências Agroveterinárias (CAV), Universidade do Estado de Santa Catarina (UDESC), Avenida Luiz de Camões 2090, Bairro Conta Dinheiro, Lages, SC 88520-000, Brazil. *Corresponding author: aldo.gava@udesc.br
}

da planta foram coletadas de cada piquete e imediatamente fornecidas na dose de $10 \mathrm{~g} / \mathrm{Kg}$ de peso vivo para 8 bezerros com idades entre 5 meses a 1 ano. Exames clínicos foram realizados antes e durante fornecimento da planta. Folhas verdes de estrela africana foram submetidas ao teste do papel picro-sódico para verificar a presença de ácido cianídrico e ao teste da difenilamina para avaliar a concentração de nitrato. Sinais clínicos de intoxicação pela grama estrela cv. "Florico" nos bovinos foram observados entre 5 e 15 minutos após o término da ingestão, estes incluíram andar cambaleante, tremores musculares, micção frequente e/ou em gotejamento, taquicardia, atonia ruminal, depressão, mucosas oculares e sangue venoso de coloração vermelho-vivo. Três animais adoeceram gravemente, quatro manifestaram sinais clínicos leves a moderados e um não adoeceu. Os 3 bovinos que adoeceram gravemente receberam solução de tiossulfato e 
nitrito de sódio na dose de $40 \mathrm{ml} / 100 \mathrm{~kg}$ de peso vivo, por via endovenosa (IV). Grama estrela florico produziu intoxicação em bovinos e a reação ao teste do papel picro-sódico e difenilamina foi mais significativa para as amostras cultivadas à sombra e com alta adubação nitrogenada. Utilização de grama florico deve ser evitada em sistema silvipastoril.

TERMOS DE INDEXAÇÃO: Reprodução experimental, intoxicação cianogênica, grama estrela, Cynodon nlemfuensis, Florico cultivar, bovinos, ácido cianídrico, sombra.

\section{INTRODUCTION}

Grasses from the genus Cynodon have been widely used in cattle feeding as it is a good quality forage, and can be used for grazing or as hay. Many studies have reported on means to improve the forage potential of plants of this genus (Vilela \& Alvim 1998).

The Cynodon genus is divided in two groups: the Bermuda grasses (Cynodon dactylon (L) Pers.), which have rhizomes and stolons, and the star grasses (Cynodon nlemfuensis Vanderyst, Cynodon aethiopicus, Clayton e Harlan), which have only stolons. This characteristic confers advantages to the first group, as for example, better resistance to grazing (Nascimento et al. 2002) and resistance to moderately cold winters (Vilela \& Alvim 1998). Among the Bermuda grass hybrids, the best known are the Tiftons, while among the star hybrids, one of the most used cultivars is the Florico (Vilela \& Alvim 1998).

The Florico star grass cultivar has a large potential cyanogenic glycoside accumulation, mainly under high nitrogen fertilization, and principally during the initial stages of the development of the plant. However, during 16 years of tests in Ona, Florida, no poisoning by hydrocyanic acid (HCN) was observed in cattle grazing on Florico grass (Mislevy et al. 1993). In Brazil, the presence of HCN in the cultivar Florico was correlated with the cutting age of this grass, but no poisoning was observed (Castro 1998).

In Brazil, the integration between agriculture, livestock, and forest, or the silvopastoral system, has been studied since 1970. Some grasses that have shown good results in this system are Panicum maximum, Brachiaria decumbens, and Brachiaria brizanta (Garcia et al. 2013). In Santa Catarina State, the silvopastoral system has been used because the shade provides greater comfort to dairy cattle. Star grasses have been recommended in this context, because they have strong stolons that grow very rapidly (Hanna \& Sollenberger 2007). The use of cv. Florico star grass cultivated in the shade provided the accumulation of hydrocyanic acid in the plant and its consumption by the bovines resulted in cyanogenic poisoning (Molossi 2019).

The current study aimed to evaluate the effect of sunlight and nitrogen fertilization on the HCN production and nitrate accumulation in Cynodon nlemfuensis Vanderyst var. nlemfuensis cv. "Florico", and to verify the cyanogenic poisoning potential of this plant in cattle.

\section{MATERIALS AND METHODS}

Star grass seedlings cv. "Florico" were collected from one of the farms where the hydrocyanogenic poisoning was encountered, and were planted in a shaded $200 \mathrm{~m}^{2}$ paddock, (under eucalyptus trees - Eucalyptus), in 2016. This Paddock (1) received proportionally $750 \mathrm{~kg} / \mathrm{ha}$ of urea.
In 2017, another six paddocks were planted with Florico star grass from the same origin; three of these were in a shaded area (under eucalyptus trees - Eucalyptus; Paddocks 2, 3, and 4, each $53 \mathrm{~m}^{2}$ in size) and three other paddocks were in a sunny area (Paddocks 5, 6, and 7, each $100 \mathrm{~m}^{2}$ in size). Paddocks 2 and 5 and Paddocks 3 and 6 received, respectively, the equivalent of 200 and $100 \mathrm{~kg} / \mathrm{ha}$ of urea, while Paddocks 4 and 7 did not receive urea fertilization. With the exception of Paddock 1, the amount of nitrogen fertilization was applied following the Brazilian Society of Soil Science (2004) manual, which recommends an amount of $100-200 \mathrm{~kg} / \mathrm{ha}$ to tropical perennial grasslands. All paddocks were planted in CAV-UDESC lands, in Lages/SC.

For experimental reproduction, the animals were weighed, fasted for 24 hours, and placed in individual stalls with water ad libitum. Green star grass leaves were collected from each paddock and immediately used to feed 8 crossbred bovines, aged from 5 months to 1 year ( 1 animal per paddock, except for Paddock 1 , where 2 animals were used), at a dose of $10 \mathrm{~g} / \mathrm{kg}$ of live weight.

The experiment was performed following procedures approved by the Committee of Ethics in Animal Experimentation of the State University of Santa Catarina (CETEA-UDESC), protocol number 9925244116.

Clinical examinations were made before, during, and after feeding the animals the star grass. Behavioral and postural alterations, as well as the color of the mucous membranes and of the blood, the corporal temperature, gastrointestinal motility (ruminal movements), and cardiac and respiratory frequencies were evaluated. The intensity of these clinical signs of poisoning was classified as mild, moderate, and severe.

In cases of mild and moderate poisoning, the animals were observed until they had recovered. When cyanogenic poisoning was severe, the bovines were treated with a solution containing $30 \mathrm{~g}$ of sodium thiosulphate and $20 \mathrm{~g}$ of sodium nitrite, dissolved in $500 \mathrm{ml}$ of distilled water, at a dose of $40 \mathrm{ml} / 100 \mathrm{~kg}$ of live weight, intravenously. The animals were considered to have recovered when they started eating again.

For qualitative confirmation of cyanogenic glycosides, the sodium picrate paper test was performed, as described by Henrici (1926) cited by Tokarnia et al. (2012). This test involves the utilization of white paper strips bathed in a solution of $5 \mathrm{~g}$ of sodium carbonate and $0.5 \mathrm{~g}$ of picric acid, both dissolved in $100 \mathrm{ml}$ of distilled water. Then, sixty grams of green Florico leaves were collected from each paddock; these were macerated and placed in glass jars with a lid. The paper strips were fixed to the lids, remaining suspended over the vegetal material; the glass jars remained in a vertical position. The reaction to the sodium picrate paper test was classified in terms of the intensity of the brick-red color that had developed in the paper by 20 minutes after beginning the test. The reaction was considered to be strong when the color changed to a brick-red color, moderate when the color was intermediate, and mild when it only turned orange.

For qualitative evaluation of nitrate in all star grass paddocks, the diphenylamine test was used. A solution composed of $0.5 \mathrm{~g}$ of diphenylamine, $20 \mathrm{ml}$ of distilled water, and sulfuric acid to $100 \mathrm{ml}$ (Radostits et al. 2002) was prepared. The test involved combining 1 drop of vegetal extract from the green leaves of the grass, obtained by manual pressure, with 3 drops of the reagent. The reaction was considered positive when an intense blue color could be observed in less than 10 seconds. The reaction was classified as negative, mild, moderate, and accentuated according to the intensity of the blue color. 


\section{RESULTS}

The clinical signs of experimental poisoning by star grass $\mathrm{cv}$. "Florico" in cattle were observed from 5 to 15 minutes after the end of ingestion and showed a variation in intensity that

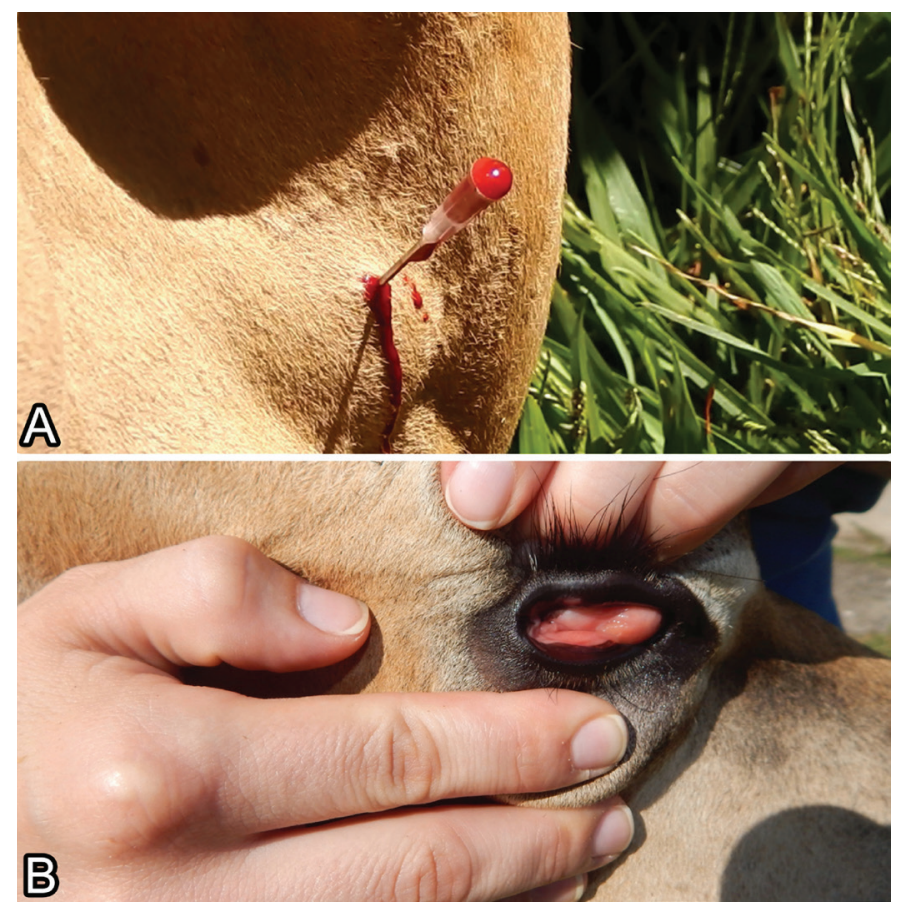

Fig.1. Experimental poisoning with star grass cv. "Florico" in Bovine 1. (A) Venous blood and (B) ocular mucous membranes; both were a bright red color. depended on the sunlight exposure and the fertilization used. The animals that ingested the plant cultivated in a shaded area (Bovine 1, Paddock 1, $750 \mathrm{~kg}$ urea/ha; and Bovine 3, Paddock 2, $200 \mathrm{~kg}$ urea/ha) and in a sunny area (Bovine 6, Paddock 5, $200 \mathrm{~kg}$ urea/ha), showed a severe cyanogenic poisoning, with clinical signs characterized by wobbling, muscle tremors, frequent and/or dripping urination, tachycardia, ruminal atony, depression, and ocular mucous membranes and venous blood of a bright red color (Fig.1). The clinical condition of Bovine 1 evolved into lateral recumbency with intense dyspnea 10 minutes after ingesting the plant. Bovines 3 and 6 showed a less severe clinical condition that lasted for a longer period and evolved into sternal recumbency, although they did manage to get up. The antidote solution was used in these 3 bovines, and the clinical condition was reversed successfully. Bovine 2 (Paddock 1, in a shaded area, $750 \mathrm{~kg}$ urea/ha), Bovine 5 (Paddock 4 without fertilization, in a shaded area), Bovine 7 (Paddock 6, in a sunny area, $100 \mathrm{~kg}$ urea/ha), and Bovine 8 (Paddock 7, in a sunny area, without fertilization), showed frequent and dripping urination, alert behavior, tachycardia, ruminal atony, and spontaneously stopped eating, consuming smaller doses than the bovines that became severely ill. Bovine 4 did not become ill at all. The data relative to the amount of plant provided, amount of plant ingested, consummation time, and onset, intensity, and duration of the clinical signs are shown in Table 1.

As shown in Table 2, star grass from shaded paddocks that had received more fertilizer demonstrated a stronger reaction in the sodium picrate and diphenylamine tests. Figure 2 shows the representative results of a strong and a mild reaction in the sodium picrate paper test and a strong as well as a negative reaction in the diphenylamine test.

Table 1. Details of star grass "Florico" supply, intensity, and evolution of the clinical signs in bovines

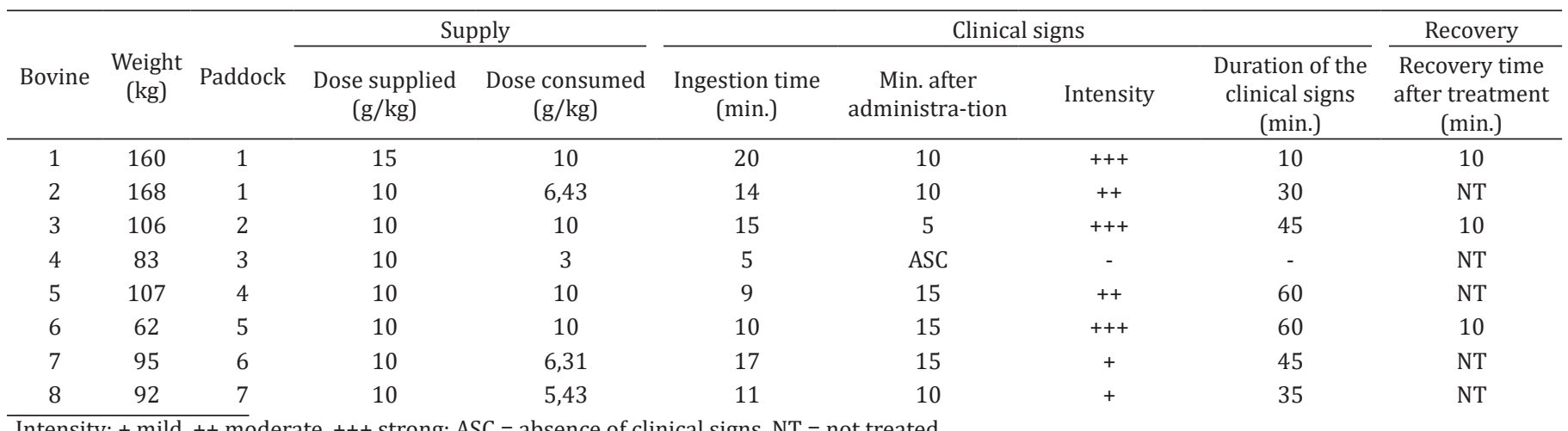

Intensity: + mild, ++ moderate, +++ strong; ASC = absence of clinical signs, NT = not treated.

Table 2. Results of the sodium picrate paper test and the diphenylamine test in star grass "Florico" cultivated in shaded and sunny areas, with and without nitrogen fertilization

\begin{tabular}{|c|c|c|c|c|}
\hline \multirow{2}{*}{$\begin{array}{l}\text { Fertilization } \\
\text { (kg urea/ha) }\end{array}$} & \multicolumn{2}{|c|}{$\begin{array}{c}\text { Shadow } \\
\text { (Paddocks 1, 2, 3, and 4) }\end{array}$} & \multicolumn{2}{|c|}{$\begin{array}{c}\text { Sunny } \\
\text { (Paddocks 5, 6, and 7) }\end{array}$} \\
\hline & $\begin{array}{l}\text { Intensity of reaction of the } \\
\text { sodium picrate paper test }\end{array}$ & $\begin{array}{l}\text { Intensity of reaction of the } \\
\text { diphenylamine test }\end{array}$ & $\begin{array}{l}\text { Intensity of reaction of the } \\
\text { sodium picrate paper test }\end{array}$ & $\begin{array}{c}\text { Intensity of reaction of the } \\
\text { diphenylamine test }\end{array}$ \\
\hline 750 & +++ & +++ & Not used & Not used \\
\hline 200 & +++ & +++ & ++ & ++ \\
\hline 100 & +++ & +++ & + & + \\
\hline WF & ++ & - & + & - \\
\hline
\end{tabular}

- Negative reaction, + mild reaction, ++ moderate reaction, +++ strong reaction; WF = without fertilization. 

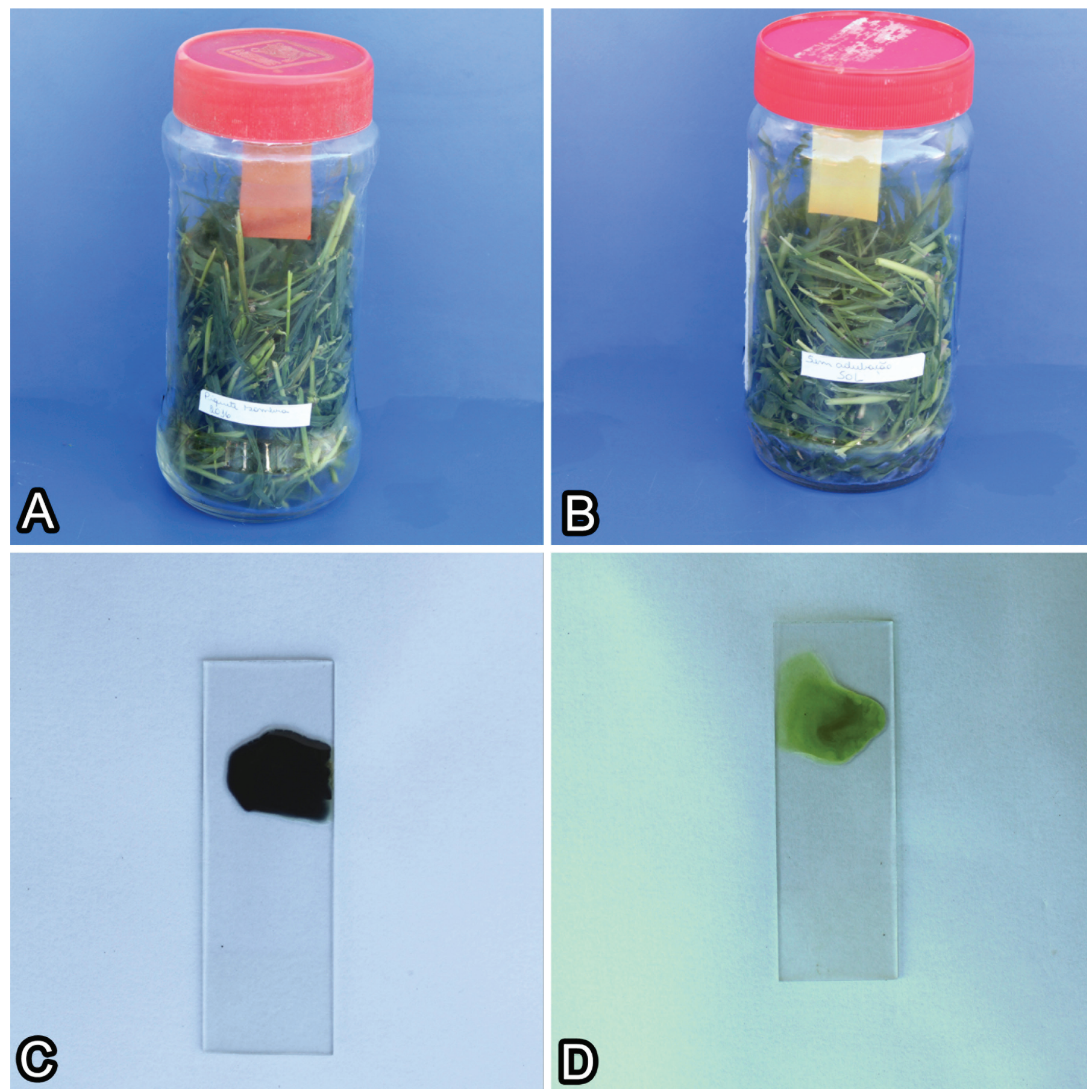

Fig.2. Reactions to the sodium picrate paper test and the diphenylamine test in star grass cv. "Florico". (A) Strong reaction to sodium picrate paper test. (B) Mild reaction to sodium picrate paper test. (C) Strong reaction to diphenylamine test. (D) Negative reaction to diphenylamine test.

\section{DISCUSSION}

The clinical condition of the experimental poisoning by star grass cv. "Florico" was marked by the rapid (5-15 min) appearance of muscle tremors, dyspnea, ruminal atony, bloat, wobbling, frequent and/or dripping urination, tachycardia, depression, ocular mucous membranes and venous blood of a bright red color, and sternal or lateral recumbency. This clinical condition is similar to that described in relation to cyanogenic plants by other authors (Saad \& Camargo 1967, Canella et al.
1968, Kellerman et al. 1988, Gava et al. 1992, Tokarnia et al. 1994a, 1994b, 1999, Gava et al. 1997, Radostits et al. 2002, Youssef \& Maxie 2004, Amorim et al. 2005, Nóbrega Junior et al. 2006, Riet-Correa \& Mendez 2007, Oliveira et al. 2008, Carvalho et al. 2011, Juffo et al. 2012, Galindo et al. 2017).

In the current study, the bovines that ate star grass cv. "Florico" from paddocks in a shaded area, and that had received good fertilization, were most severely clinically affected. Similarly, the paddocks in a shaded area with more 
fertilization resulted in a stronger reaction to the sodium picrate paper test. This is in accordance with what occurs in the spontaneous poisoning described by Molossi (2019). Vetter \& Haraszti (1977), observed that the HCN production in Sorghum spp. gradually decreased during its vegetative growing, while the photosynthesis intensity increases, in other words, as photosynthesis decreased, more HCN was produced. Higher HCN levels are due to many factors; among these are a young age of the plants, a rapid growth rate, high nitrogen fertilization, low growing periods followed by rain, wilting, plants burnt by cold weather, and resprouting (Harris \& Shearer 1994, Radostits et al. 2002).

According to Vetter (2000), a greater availability of nitrogen in the soil promotes cyanogenic glycosides production. Tapper \& Reay (1973) described that nitrogen is part of the chemical composition of the known cyanogenic glycosides. Mislevy et al. (1993) affirmed that the hydrocyanic potential of star grass "Florico" is high under heavy nitrogen fertilization, especially during the initial stages of development of the plants.

Cruz (1997) observed that the nitrogen content increased in shaded pastures. This may occur because the soil in a shaded area tends to have greater humidity, associated with the moderate temperature, resulting in more rapid nitrogen mineralization, decomposition of organic matter, and recycling of this matter (Belsky et al. 1993). According to Wilson Junior \& Ludlow (1991), the greater amount of nitrogen in the leaves is a compensatory mechanism that results in more $\mathrm{CO}_{2}$ assimilation, leading to a more efficient use of solar radiation in shaded pastures. In shade, plants invest less than half of the nitrogen in their leaves in photosynthesis, which thus increases the nitrogen proportion in leaves (Evans 1993). This is also in agreement with the observations of the current study, in relation to nitrate presence, where the diphenylamine test showed a tendency for higher nitrate levels in star grass cv. "Florico" cultivated in a shaded area and/or with a higher levels of fertilization. Poisoning by nitrate does not occur in this situation, as the HCN present in the plants has a rapid action, which hampers ingestion of the larger amounts that are necessary for nitrate poisoning.

The response to the sodium picrate paper test with the star grass cv. "Florico", which was observed after 20 minutes, was different from that obtained from green and tender leaves of Prunnus sellowii, which occurred from 3 to 5 minutes after the maceration of this plant (Gava et al. 1992). This may be due to the higher fibrous content of this grass, which makes the trituration of the vegetal matter more difficult, and thus affects the reaction between the enzyme and the glycosides. Some plants that are potentially dangerous to animals always have a rapid effect, while the effect of others are slower because of the glycoside stability (some are less volatile) and the enzymes available for hydrolysis (Tokarnia et al. 1999). The plants with slower effects have less toxicity and the related clinical conditions demonstrate a longer, slower evolution (Amorim et al. 2005, Tokarnia et al. 1999). In the current study, 4 of 8 bovines spontaneously ceased star grass ingestion. This indicates that some animals, when ingesting the plant more slowly, perceive that it made them feel indisposed and therefore rejected the plant food, avoiding aggravation of their condition. Bovine 1 ingested the star grass greedily and manifested severe cyanogenic poisoning signs. A solution containing sodium thiosulfate and sodium nitrite was used successfully to treat the experiment animals, as previously described by Radostits et al. (2002) and Galindo et al. (2017).

\section{CONCLUSIONS}

External factors, such as shade and fertilization promote HCN accumulation in star grass (Cynodon nlemfuensis Vanderyst var. nlemfuensis cv. "Florico") and cause cyanogenic poisoning in bovines when more than $5 \mathrm{~g} / \mathrm{kg}$ live weight is ingested.

Florico grass utilization should be avoided in a silvopastoral system.

Acknowledgments.- The first author thanks the Coordination of Improvement of Higher Education Personnel (CAPES) for the scholarship of the master's degree.

Conflict of interest statement.- The authors have no competing interests.

\section{REFERENCES}

Amorim S.L., Medeiros R.M.T. \& Riet-Correa F. 2005. Intoxicação experimental por Manihot glaziovii (Euphorbiaceae) em caprinos. Pesq. Vet. Bras. 25(3):179-187. <http://dx.doi.org/10.1590/S0100-736X2005000300009>

Belsky A.J., Mwonga S.M., Amundson R.G., Duxbury J.M. \& Ali A.R. 1993. Comparative effects of isolated trees on their under canopy environments in high- and low-rainfall savannas. J. Appl. Ecol. 30(1):143-155. <http:// dx.doi.org/10.2307/2404278>

Brazilian Society of Soil Science 2004. Manual de Adubação e Calagem para os Estados do Rio Grande do Sul e Santa Catarina. Química do Solo e Comissão de Fertilidade, Sociedade Brasileira de Ciência do Solo. 10 $0^{\underline{a}}$ ed. Porto Alegre, p.155-160.

Canella C.F.C., Dobereiner J. \& Tokarnia C.H. 1968. Experimental poisoning by maniçoba (Manihot glaziovii Muell. Arg.) in bovines. Pesq. Agropec. Bras. 3:347-350.

Carvalho F.K.L., Medeiros R.M.T., Araujo J.A.S. \& Riet-Correa F. 2011. Intoxicação experimental por Passiflora foetida (Passifloraceae) em caprinos Pesq. Vet. Bras. 31(6):477-481. <http://dx.doi.org/10.1590/ S0100-736X2011000600003>

Castro F.G.F. 1998. Effect of cutting age on yield, bromatological chemical composition, in vitro dry matter and organic matter digestibility, and hydrocyanic acid content of Cynodon nlemfuënsis Vanderyst var. nlemfuënsis cv. “Florico”. Master's Thesis, Universidade de São Paulo, São Paulo, SP. 150p.

Cruz P. 1997. Effect of shade on the carbon and nitrogen allocation in a perennial tropical grass, Dichanthium aristatum. J. Experimental Botany 48(1):15-24. <http://dx.doi.org/10.1093/jxb/48.1.15>

Evans J.R. 1993. Photosynthetic acclimation and nitrogen partitioning within a lucerne canopy. I. Canopy characteristics. Austr. J. Plant Physiol. 20:55-67.

Galindo C.M., Hemckmeier D., Biondo N., Parizotto L.H., Ogliari D. \& Gava A. 2017. Intoxicação espontânea e experimental por tifton 68 (Cynodon nlemfuensis Vanderyst) em bovinos. Pesq. Vet. Bras. 37(5):441-446. <http:// dx.doi.org/10.1590/s0100-736x2017000500003>

Gava A., Pilati C., Cristani J., Simoes J. \& Simoes L. 1997. Cyanogenic intoxication in cattle fed with Tifton (Cynodon sp.). Anais VIII Ciclo de Atualização em Medicina Veterinária (CAMEV), UDESC, Lages, SC, p.119.

Gava A., Stolf L., Neves D.S., Stolf O., Varaschim M.S. \& Ferreira E.M.M. 1992. Intoxicação experimental por Prunus sellowii (Rosaceae) em bovinos. Pesq. Vet. Bras. 12(1/2):1-4.

Hanna W.W. \& Sollenberger L.E. 2007. Tropical and subtropical grasses, p.245-255. In: Barnes R.F., Nelson C.J., Moore K.J. \& Collins M. (Eds), Forages the Science of Grassland Agriculture. Vol.2. 6th ed. Wiley, New Jersey.

Harris B. \& Shearer K.J. 1994. Nitrate, prussic acid (HCN) and grass tetany problems in cattle feeding. Dairy Sci. 6:1-3. 
Juffo G.D., Pavarini S.P., Wouters F., Oliveira L.G.S., Antoniassi N.A.B., Cruz C.E.F. \& Driemeier D. 2012. Intoxicação espontânea por Sorghum sudanense em bovinos leiteiros no Rio Grande do Sul. Pesq. Vet. Bras. 32(3):217-220. <http://dx.doi.org/10.1590/S0100-736X2012000300006>

Kellerman T.S., Coetzer J.A.W. \& Naudé T.W. 1988. Haemopoietic system, p.193-213. In: Ibid. (Eds), Plant Poisonings and Mycotoxicoses of Livestock in Southern Africa. Oxford University Press, Cape Town.

Mislevy P., Brown W.F., Caro-Costas R., Vicente-Chandler J., Dunavin L.S., Hall D.W., Kalmbacher R.S., Overman A.J., Ruelke O.C., Sonoda R.M., Sotomayor-Rios A., Stanley Junior R.L. \& Williams M.J. 1993. Registration of Florico stargrass. Crop Sci. 33(2):358-359. <http://dx.doi.org/10.2135/ cropsci1993.0011183X003300020044x>

Molossi F.A., Ogliari D., Morais R.M., Wicpolt N.S., Gheller E., Weber L. \& Gava A. 2019. Cyanogenic poisoning by spontaneous ingestion of star grass (Cynodon nlemfuensis var. nlemfuensis cv. 'Florico') in cattle. Pesq. Vet. Bras. 39(1):20-24.

Nascimento M.P.S.C.B., Nascimento H.T.S. \& Leal J.A. 2002. Comportamento de cultivares de Cynodon em Piauí. Comunicado Técnico 146, EmbrapaCNPMN, Teresina. 3p.

Nóbrega Junior J.E., Riet-Correa F., Medeiros R.M.T. \& Dantas A.F.M 2006. Intoxicação por Sorghum halepense (Poaceae) em bovinos semi-áridos. Pesq. Vet. Bras. 26:201-204.

Oliveira D.M., Pimentel L.A., Araújo J.A.S., Rosane M.T.M., Dantas A.F.M. \& RietCorrea F. 2008. Intoxicação por Cnidoscolus phyllacanthus (Euphorbiaceae) em cabras. Pesq. Vet. Bras. 28(1):36-42. <http://dx.doi.org/10.1590/ S0100-736X2008000100006>

Radostits O.M., Gay C.C., Blood D.C. \& Hinchcliff K.W. 2002. Doenças causadas por toxinas de plantas, fungos, cianófitas, clavibactérias e venenos de carrapatos e animais vertebrados, p.1472-1547. In: Ibid. (Eds), Clínica Veterinária: um tratado sobre doenças de bovinos, ovinos, caprinos, suínos e equinos. 9a ed. Guanabara Koogan, Rio de Janeiro.

Riet-Correa F. \& Mendez M.C. 2007. Poisoning by plants and mycotoxins, p.177-181. In: Riet-Correa F., Schild A.L., Lemos R.A.A. \& Borges J.R.J. (Eds), Ruminantes e Doenças Equinas. Vol.2. $3^{a}$ ed. Pallotti, Santa Maria.
Saad A.D. \& Camargo W.V.A. 1967. Intoxicação cianídrica em animais domésticos. Arqs Inst. Biológico, São Paulo, 33:211-220.

Tapper B.A. \& Reay P.F. 1973. Cyanogenic glycosides and glucosinolates. p.447-476. In: Butler C.W. \& Bailey R.W. (Eds), Chemistry and Biochemistry of Herbage. Vol.1. Academic Press, London, New York.

Tokarnia C.H., Dobereiner J. \& Peixoto P.V. 1994a. Aspectos clínico-patológicos complementares da intoxicação por algumas plantas tóxicas brasileiras. Pesq. Vet. Bras. 14:111-122.

Tokarnia C.H., Peixoto P.V. \& Dobereiner J. 1994b. Intoxicação experimental por Piptadenia macrocarpa (Leg.Mimosoideae) em bovinos. Pesq. Vet. Bras. 14:57-63.

Tokarnia C.H., Peixoto P.V., Brito M.F., Duarte M.D. \& Brust L.A.C. 1999. Estudos experimentais com plantas cianogênicas em bovinos. Pesq. Vet. Bras. 19(2):84-90.<http://dx.doi.org/10.1590/S0100-736X1999000200006>

Tokarnia C.H., Brito M.F., Barbosa J.D., Peixoto P.V. \& Dobereiner J. 2012. Plantas Tóxicas do Brasil: para animais de produção. $2^{\mathrm{a}}$ ed. Helianthus, Rio de Janeiro, p.443-459.

Vetter J. 2000. Plant cyanogenic glycosides. Toxicon 38(1):11-36. <http:// dx.doi.org/10.1016/S0041-0101(99)00128-2> <PMid:10669009>

Vetter J. \& Haraszti E. 1977. Changes in the hydrogen cyanide content of Sudan grass (Sorghum sudanense) and broomcorn (Sorghum bicolor var. technicum) during the growing season. Acta Agron. Sci. Hung. 26:15-22.

Vilela D. \& Alvim M.J. 1998. Manejo de pastagens do gênero Cynodon: introdução, caracterização e evolução do uso no Brasil. Anais XV Simpósio sobre Manejo de Pastagens, Fundação de Estudos Agrários "Luiz de Queiroz" (FEALQ), Piracicaba, p.23-54.

Wilson Junior \& Ludlow M.M. 1991. The environment and potential growth of herbage under plantations, p.10-24. In: Shelton H.M. \& Stur W.W. (Eds), Forage for Plantation Crops. XXXII ACIAR Proceedings, Australian Centre for International Agricultural Research, Canberra.

Youssef S. \& Maxie M.G. 2004. Nervous system, p.347-348. In: Ibid. (Eds), Jubb, Kennedy and Palmer Pathology of Domestic Animals. Vol.3. 5th ed. Academic Press, London. 